Abstracta Iranica Iranica

Revue bibliographique pour le domaine irano-aryen

Volume 37-38-39 | 2018

Comptes rendus des publications de 2014-2016

\title{
Geoffrey Herman (ed.). Jews, Christians and Zoroastrians. Religious Dynamics in a Sasanian Context
}

Christelle Jullien

\section{(2) OpenEdition Journals}

Édition électronique

URL : http://journals.openedition.org/abstractairanica/42591

DOI : 10.4000/abstractairanica.42591

ISBN : 1961-960X

ISSN : 1961-960X

Éditeur :

CNRS (UMR 7528 Mondes iraniens et indiens), Éditions de l'IFRI

Référence électronique

Christelle Jullien, « Geoffrey Herman (ed.). Jews, Christians and Zoroastrians. Religious Dynamics in a Sasanian Context », Abstracta Iranica [En ligne], Volume 37-38-39 | 2018, document 1, mis en ligne le 10 mars 2018, consulté le 28 septembre 2020. URL : http://journals.openedition.org/abstractairanica/ 42591 ; DOI : https://doi.org/10.4000/abstractairanica.42591

Ce document a été généré automatiquement le 28 septembre 2020.

Tous droits réservés 


\title{
Geoffrey Herman (ed.). Jews, Christians and Zoroastrians. Religious Dynamics in a Sasanian Context
}

\author{
Christelle Jullien
}

\section{RÉFÉRENCE}

Geoffrey Herman (ed.). Jews, Christians and Zoroastrians. Religious Dynamics in a Sasanian Context, (Judaism in Context 17), Piscataway: Gorgias Press, 2014, 325p. ISBN

978-1-4632-0250-7.

1 Fruit d'une table ronde tenue à la Ruhr-Universität (Bochum), l'ouvrage présente quelques exemples de contacts entre les communautés et traditions religieuses de l'empire sassanide, spécialement entre zoroastrisme, christianisme perse, manichéisme et judaïsme babylonien. La première étude propose des éléments de réflexion sur le vocabulaire et la terminologie appropriés pour aborder la question des relations entre les Églises et le pouvoir. Deux contributions portent sur les Actes des martyrs perses, l'une dans le prisme de la polémique mazdéo-chrétienne, l'autre ayant trait à la persécution anti-chrétienne attribuée à Yazdgird $\mathrm{I}^{\mathrm{er}}$, ici rediscutée. D’autres interventions s'intéressent au façonnement de modèles historiographiques (Mani, figure des mages évangéliques), ou au milieu judaïque babylonien dans ses rapports avec d'autres communautés religieuses - un aspect jusqu'ici assez peu étudié. 


\section{AUTEURS}

\section{CHRISTELLE JULLIEN}

CNRS, Mondes iranien et indien 